\title{
Analfistel - ikke bare en kongelig lidelse
}

\begin{abstract}
I dette nummer av Tidsskriftet er det en artikkel om hvordan Solkongen, Ludvig 14 av Frankrike, slet med en analfistel. Å behandle slike i 1680 -årene var ingen enkel oppgave, men man valgte til slutt et kirurgisk inngrep med en for anledningen oppfunnet sonde. Da dette var vellykket, fikk kirurgifaget større prestisje og bedre arbeidsforhold. Hvordan sto det til med fistelkunnskapen og -behandlingen 250 år etter (Tidsskr Nor Lægeforen 1937; 57: 1161-8)?
\end{abstract}

\section{Om fistler.}

\author{
Klinisk forelesning for studenter.
}

Av Sofus Widerøe, Oslo.

$(\ldots)$

\section{Behandlingen.}

Når fisteldiagnosen er stillet, er behandlingen gitt. En dermoidfistel helbredes først når dermoidcysten er eksstirpert. Urachusfistelen først når hele kanalen er fjernet. En halsfistel, medial eller lateral må ekscideres in toto.

De simple fistler er takknemlige å behandle. Pointet i denne behandling er korrekt drenasje. Et langt drenrør må aldri fjernes. Det må forkortes sukcessivt. Fjernes et langt drenrør, vil fistelåpningen forsnevres eller lukkes. Granulasjonsvevet bak åpningen sesernerer alltid pus. Følgen blir retensjon. Er åpningen lukket, dannes der en abscess. Der kommer svulst, smerter og kanskje almenreaksjon med temperaturstigning.

Den feil å fjerne et langt drenrør begås meget ofte. Det må betegnes som en kunstfeil å fjerne et langt drenrør. Her er sondeundersøkelsen nødvendig for å avgjøre fistelens lengde. Drenrøret må alltid være noget kortere enn fistelen. Det sier sig selv hvorledes fremgangsmåten blir.

Det hender undertiden at en fistel blir drenert for lenge og at tilhelingen av den grunn unødig forlenges. Jeg har sett mange eksempler på det.

Det fremgår av det ovenfor nevnte, hvorledes dette kan undgåes.

Blant de simple fistler inntar, som tidligere nevnt, de anale fistler en meget fremtredende plass. Det er mitt inntrykk at disse patienter ofte blir slett behandlet. De kan gå i årrekker med sin fistel. De behandles med suppositorier eller med borvannsomslag om natten uten nogen effekt. En analfistel bør alltid behandles kirurgisk.

Diagnosen fistula ani er lett å stille. Vanskeligere er det å avgjøre om fistelen er anal., d.v.s. om den ligger utenfor anus eller om dens utgangspunkt ligger høiere, d.v.s. om den er ischiorektal eller pelvirektal.

Den skablonmessige behandling med de kun symptomatisk virksomme stikkpiller av forskjellig sammensetning er berettiget som en symptomatisk behandling, men aldri som kausalbehandling. Fistula ani er en kirurgisk lidelse som alltid - så tidlig som mulig - må henvises til en kirurg.

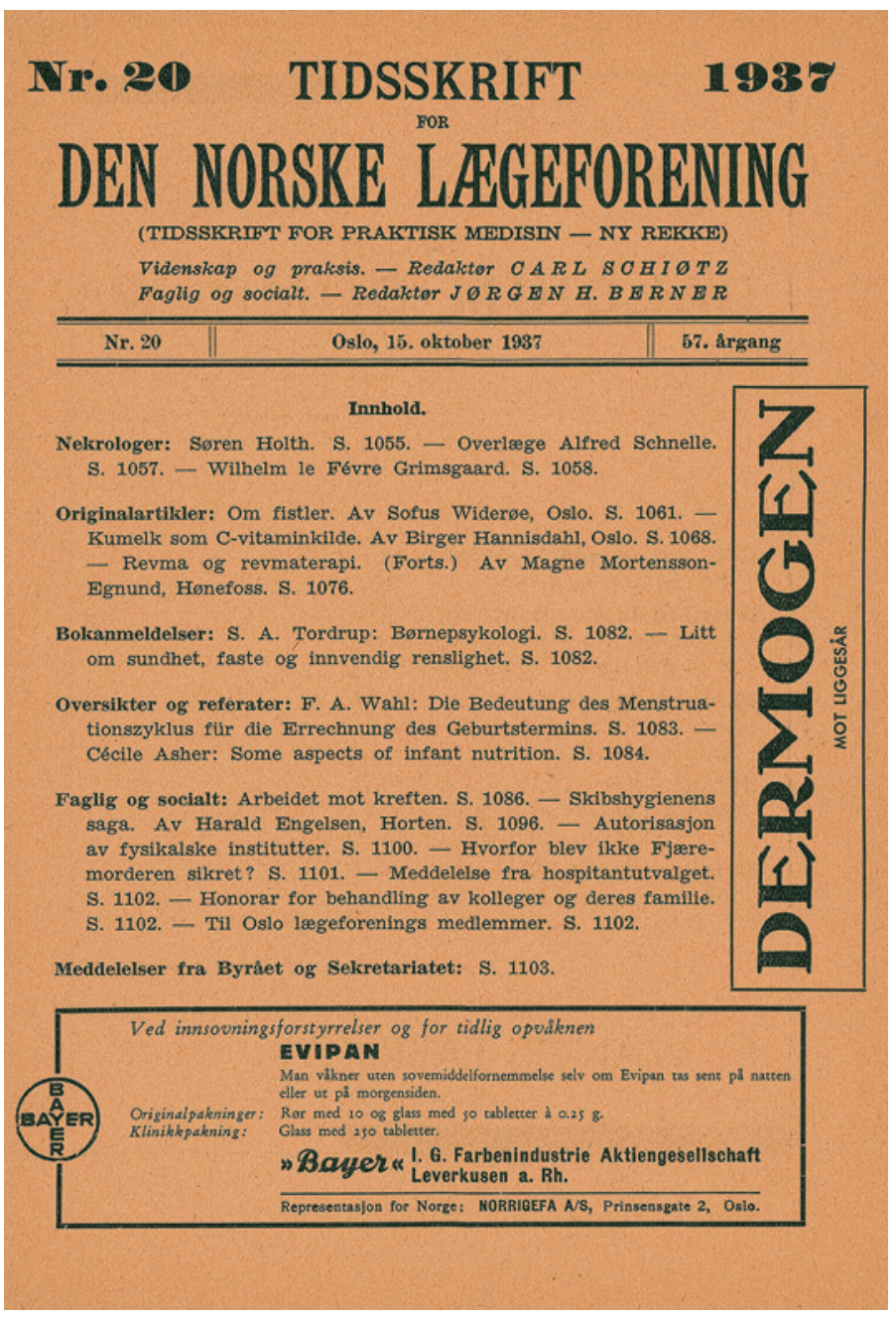

